\title{
ДО ПИТАННЯ ПЕРШОГО СЦЕНІЧНОГО ВТІЛЕННЯ П'СС Л. СТАРИЦЬКОЇ-ЧЕРНЯХІВСЬКОЇ «ГЕТЬМАН ДОРОШЕНКО», «КРИЛА» ТА «ОСТАННІЙ СНІП» НА СЦЕНІ ТЕАТРУ МИКОЛИ САДОВСЬКОГО (До 150-річчя від дня народження письменниці)
}

У статті вперше зроблено спробу реконструкцї сиенічних версій найкращих різножанрових драматичних творів талановитої письменниці Л. М. Старицької-Черняхівської- «Гетьман Дорошенко», «Крила» та «Останній сніп».

Ключові слова: символічна драма, історична драма, психологічна драма, жанр драматичного твору, модернізм, стилізаџія, режисерська інтерпретаџія n'єси, акторське виконання.

В статье впервые сделана попытка реконструкиии сценических версий лучших разножанровых драматических произведений талантливой писательниць Л. М. Стариикой-Черняховской - Гетьман Дорошенко», «Крылья» и «Последний сноп».

Ключевые слова: символическая драма, историческая драма, психологическая драма, жанр драматического произведения, модернизм, стилизация, режиссёрская интерпретация пьесы, актёрское исполнение.

The article first attempts to reconstruct stage versions of the best dramatic works in different genres of talented writer Liudmyla Mykhailivna Starytska-Cherniakhivska - «Hetman Doroshenko», "The Wings» and "The Last Sheave».

Key words: symbolic drama, historical drama, psychological drama, genre of dramatic work, modernism, stylization, director's interpretation of the play, acting performance.

Людмила Михайлівна Старицька (після одруження Старицька-Черняхівська) народилася 28 серпня (у деяких документах - 29 серпня) 1868 року в селі Карпівка Могилів-Подільського повіту Подільської губернії (тепер Вінницька обл.) у старовинній дворянській родині. Батько ii - відомий український письменник, драматург, один із корифеїв професіонального театру Михайло Петрович Старицький, а мати, Софія Віталіївна, - рідна сестра класика української музики, композитора Миколи Лисенка. У сім'ї Старицьких Людмила була молодшою донькою улюбленицею батька, - тому, мабуть, і перейняла майже всі його таланти. В українську культуру вона увійшла авторкою високохудожніх прозових творів, творцем видатних оригінальних п'єс, поетесою, публіцисткою, лібретисткою (лібрето до кількох опер Лисенка), перекладачкою на українську мову творів німецьких, французьких та російських авторів, рецензенткою, театрознавцем, мемуаристкою, а також полум'яною громадською діячкою, яка до самозабуття любила рідну Україну.

Разом 3 батьком написала історичні романи «Перед бурею» та «Останні орли». Ї̈̈ перу належать п’єси «Сапфо» (1908), «Аппій Клавдій» (1909), «Гетьман Дорошенко» (1911), «Крила» (1913) і лібрето до опер М. Лисенка «Енеїда» та «Ноктюрн».

У 1914-1919 роках Людмила Старицька включилась в активну громадсько-політичну діяльність. Вона стала засновником і членом Літературно-артистичного товариства у Києві, Українського клубу та Українського наукового товариства «Просвіта». Після смерті Лисенка, який очолював Український клуб, перебрала на себе його 
обов'язки, пізніше клуб відновив свою діяльність під назвою «Родина». Після Лютневої революції письменниця дуже захопилась політичними ситуаціями - масовий ентузіазм людей, свобода слова, антивоєнний рух тощо. Людмила Старицька бере активну участь у національно-визвольному русі, що реалізувався в Українську Центральну Раду, в формуванні першого уряду України, стає членом-засновником Комітету Українського Національного театру, очолює видавничу й репертуарну комісію при Генеральному Секретареві освіти. I разом $з$ тим не полишає літературної праці - у 1917 році вийшла п’єса «Останній сніп», авторка працює над драмою «Милость Божа» (1919), завершує талановиті історичні п’єси - «Розбійник Кармелюк», «Іван Мазепа», «Богдан Хмельницький» та інші.

У січні 1930 р. Л. Старицьку-Черняхівську разом 3 чоловіком О. Черняхівським, професором медицини, було заарештовано за причетність до міфічної Спілки Визволення України (СВУ). Черняхівських без вини було засуджено до п’яти років таборів і трирічного заслання. Після повернення до Києва у 1939 р. в таборах ГУЛАГу все ще перебувала їхня донька Вероніка Черняхівська-Ганжа, а пізніше, 20 липня 1941 р., Людмилу Старицьку-Черняхівську разом із сестрою Оксаною Стешенко (вдовою колишнього Генерального Секретаря освіти, письменника й науковця I. Стешенка) було знову заарештовано та вивезено на заслання до Казахстану. Під час етапу в товарному вагоні Людмила Старицька померла, і до сьогодні місце вічного спочинку цієї глибоко творчої людини залишається невідомим. Адже за часи тоталітарного більшовицького правління навіть згадувати ім'я великої патріотки української землі було заборонено.

У роки, коли починала свою творчу діяльність Л. Старицька, театральний процес, як і все мистецьке життя в Україні перших десятиліть XX ст., був надзвичайно багатим і різноплановим - тут активно діяли театри побутово-реалістичного спрямування, а також на сценах започатковувались і проростали риси модернової театральної стилістики.

У найкращих драмах Л. Старицької-Черняхівської - «Сапфо», «Аппій Клавдій», «Гетьман Дорошенко», «Крила», «Останній сніп» та «Іван Мазепа», де глибока обізнаність письменниці 3 «новою» драмою, «тонке відчуття прийомів стилізації виявилися передусім у виборі авторкою актуальної для модерністських пошуків тематики» $[14,37]$, відтворених у драматургічній формі.
Літературознавці Т. Свербілова, Н. Малютіна і Л. Скорина, досліджуючи жанрово-стильову парадигму української драматургії першої третини XX ст. у своїй колективній монографії, виокремлюють, у перехідній драматургії порубіжжя, ознаки символізації образності: «Своєрідний колаж візійної символізації ознак натуралістичної і неореалістичної драми, експресіоністичного і імпресіоністичного стилів, ліризації й епізації спостерігаємо у драмах В. Пачовського, Лесі Українки, Олександра Олеся (драматургія яких найбільше відповідає поетиці символізму) <..> у деяких драмах С. Черкасенка та Л. Старицької-Черняхівської» $[14,36]$.

Сама Л. Старицька-Черняхівська у статті «Двадцять п’ять років українського театру» (1907), характеризуючи різновиди драматургічних творів - символічну драму, драму настрою і соціальну драму, об'єктом зацікавлення сучасного їй символізму вважала «сферу різноманітних моментів особистого “Я”, визволеного й незалежного од часових, соціальних та політичних форм конкретного життя, з'єднаного лише з життям природи» [17, 726]. Проте, попри безнастанну увагу дослідників до вивчення естетики модернізму і його значення у розвиткові української літератури та, зокрема, драматургії, слід зауважити, що в практичній сценічній діяльності цей стиль не став визначальною ознакою у театральній творчості. Дослідниця театрального процесу театрознавець Г. Веселовська стверджує, що в українському театрі першої третини XX ст. не відбулося визначних модерністських відкриттів: «Більше того, консервативність саме у цій справі призвела до того, що театр не зміг своєчасно витворити ні нових форм, ні дати поштовху розвиткові драматургії чи сценографії» $[5,14]$. Продовжуючи свою думку, авторка стверджує, що «в численних мистецтвознавчих розвідках не раз зазначалося, що навіть незначні модерністські просування театру забезпечувалися насамперед літературною основою чи сценічним оформленням» $[5,14]$. Відтінки модерністичних виражальних засобів, на розуміння Л. Старицької-Черняхівської, могли найбільше виявлятися у символізмі, що «одірвав драму од малювання пошлої буденщини; він нагадував нам про вічні, грунтовні проблеми людського духу, незалежні ні од соціальних, ні од політичних форм життя» $[17,739]$.

I ці «вічні і грунтовні проблеми людського духу» драматург могла висвітлювати в історичних подіях та постатях як світової, так і вітчизняної давноминувшини. Авторка сама визначала головне естетичне спрямування свого творчого 
уподобання: «Історична драма - найтриваліша форма драматичної творчості: вона не боїться подиху часу, вона не старіє, не робиться de mode (не модною (фр.). - П. К.). Разом з тим вона сливе однаково цікава всім народностям, бо переважно розробляє, хоча й пристосовані до тих або інших форм життя, але загальнолюдські мотиви: героїзм, боротьба між бажанням власного щастя й громадським обов'язком» $[17,672]$.

Історія України давала багатий матеріал для творчості письменниці-драматургові, звідси «Милость Божа», «Богдан Хмельницький», «Гетьман Дорошенко», «Іван Мазепа», «Останній сніп» та «Розбійник Кармелюк». Всі ці п’єси трактують драму як форму усвідомлення людиною суперечностей дійсності i, насамперед, як вираз суспільних суперечностей людського буття. В історичному жанрі письменниця своїм світобаченням яскраво відтворювала сучасну боротьбу українського народу проти соціальних кривд і політичних утисків: «Тепер, коли кожне з'явисько натури чарує тонке почуття людини своєю красою. Коли розум людини 3 кожною хвилиною прорубує все далі сходи в глибоке царство таїни знаття, коли люди навчилися жити кожним фібром своєї істоти, - страчувати життя - зовсім марнотратство», і далі: «Людина піднялась душею понад душі богів. 3'ясувати душевну боротьбу такого героя не можна вже настроями... цвіркунами та краплями дощу. Сама думка про те огидою проймає мозок! Велетню, богочоловіку дзеркалом може бути тільки велична драма дії та боротьби» [17, 736-737].

Такими велетнями для Л. Старицької-Черняхівської стали її улюблені герої - Богдан Хмельницький, Іван Мазепа, Устим Кармелюк, Петро Дорошенко, які збуджували ії письменницьку уяву і ставали найшанованішими для публіки персонажами у виставах, котрі висвітлювали події з історичної минувшини України та викликали асоціації з обставинами сьогоднішнього дня. Яскравою ілюстрацією наших міркувань є постановка однієї 3 кращих історичних драм Л. Старицької-Черняхівської «Гетьман Дорошенко» в одному з найсильніших у художньому відношенні - Київському театрі Миколи Садовського, першому взагалі стаціонарному українському театрі. У ньому, щоправда, модернізм не мав виразного яскравого вираження (хоча і виставляв театр модернові п'єси В. Винниченка, Ол. Олеся та С. Черкасенка). Там ознаки модерну радше виявлялися у комплексних проявах - у драматургії, акторській творчості, сценографії та музиці. I якщо в теоретичних роздумах авторка ратувала за модерновий театр, то у «Гетьманові Дорошенку» і в ідейно-тематичній трактовці, і в поетиці виразно були відчутні ознаки класично-традиційної театральної стилістики.

Прем'єра вистави «Гетьман Дорошенко» відбулася 9 листопада 1911 року. П'єсу ставив сам М. Садовський, він же й виконував центральну роль Дорошенка, що значною мірою сприяло великому художньому й матеріальному успіхові постановки і визначило надалі багату сценічну історію п’єси. Вистава народжувалась у тісній співпраці режисера і драматурга, окремі сцени, як говориться, і переписувались, і скорочувались. Пізніше М. Садовський згадував, що після завершення роботи над п'єсою авторка запросила до себе його та ще кількох акторів театру для ознайомлення 3 новим творінням. «П'єса справила на нас надзвичайне вражіння, але я звернув іiі увагу, що, на жаль, навряд щоб цензура дозволила іï, бо історична правда, виведена тут, не думаю, щоб прийшлася цензурі до смаку» $[13,108-109]$. Одначе цензуру вдалося здолати, і вона дала дозвіл для постановки на сцені цієї гостросюжетної п'єси. I коли відбулась уже прем'єра, то на першій виставі «один з чорносотенців звернувся до голови театральної комісії, теж чорносотенця <...> з запитанням: "Как вы могли разрешить к постановке такую пьесу?" На це той йому, єхидно посміхаючись, відповів: “А что же тут, по-вашему, худого? Прекрасная пьеса! Прекрасная! Мне очень нравится, и цензура разрешила"» $[13,109]$.

У сценічному втіленні «Гетьмана Дорошенка» велике значення мала обізнаність режисера в питаннях історії України, побуту, народних звичаїв та костюмів. Літературно-поетичний текст у поєднанні з реалізмом сценічного буття підносився до одухотвореного та глибоко продуманих символів мистецького узагальнення. В емоційному забарвленні вистави велику силу відігравала музика геніального М. Лисенка. Садовський згадував, що композитор «написав знаменитий марш, який так і зветься марш “Гетьмана Дорошенка". Цей марш так пасує до загального враження від самої п’єси і створював такий гнітючий настрій, що публіка плакала. Я сам, граючи (роль гетьмана Дорошенка - П. К.), ні разу не міг кінчити ролю без сліз, які мимоволі текли 3 моїх очей. Правда, вже останні сцени прощання із стягами болюче вражали, а цей марш піддавав ще більшого гніту» $[13,110]$.

Історик театру Олександр Кисіль постановку «Гетьмана Дорошенка» відносив до видатної вистави, «поставленої надзвичайно уважно з зовнішнього боку, з новими спеціальними декораці- 
ями художника I. Бурячека, стильовими меблями та вбранням» $[10,127]$.

У виставі, як і в п'єсі, центральною постаттю був М. Садовський (Дорошенко), який «оживив всю п'єсу своєю натхненною грою, такою барвистою, соковитою й глибоко щирою» [16]. У сценічному виконанні М. Садовським роль гетьмана Дорошенка належала до вершин акторської майстерності митця у жанрі героїко-романтичних і трагедійних образів. Цьому сприяли не лише його зовнішні і внутрішні дані, якими природа щедро обдарувала майстра: велична постать, глибокий темперамент, мужній вираз обличчя, чистий i сильний голос, пластичність тіла, а й знання та використання автобіографічних та історичних умов, у яких жив і діяв його персонаж. Все життя і діяльність Петра Дорошенка були спрямовані на досягнення повної державної незалежності та збереження територіальної цілісності України. Саме ці ідеї героя були близькими світоглядним поглядам М. Садовського, адже напередодні Першої світової війни актуально поставала проблема єдності українських земель, бо у роки війни трагедія українського народу вже вкотре повторилася - українці входили як до австрійської, так і до російської армій і змушені були вбивати один одного.

Дорошенко Садовського сприймався глядачами як воїн, політик-філософ, гуманіст, великий патріот і вболівальник за долю рідного краю. Театральний рецензент В. Чаговець зауважував: «Важко розмежувати, що дано автором і що зроблено актором, але Дорошенко вийшов найбільш випуклий і цікавий» [20]. До найкращих сцен Сaдовського-Дорошенка рецензенти зараховували прийом московського посланця (Є. Рибчинський), де Дорошенко спершу звинувачував Російську державу за укладення з Польщею Андрусівського мирного договору, що остаточно поділив українські землі на два гетьманати: Лівобережний, підпорядкований Росії, та Правобережний - Польщі. Внаслідок цього в українських землях почався період кривавих заколотів та міжусобиць, які підривали сили народу, руйнували господарство, а значні простори української території перетворювались у пустелю. У зустрічі зрештою відбувався кульмінаційний момент. Садовський-Дорошенко рішуче стверджував, що «я гетьман від голови до п'яти», а після цього наважився нагадати Московії про переяславські угоди та про іï зрадницьку політику:

«Скажи мені,

Хто право дав вам нами торгувати?
Не шаблею взяли нас. Гетьман наш

Богдан Хмельницький, сам по добрій волі

Злучився із Москвою, знаєш як?

Як вільний з вільним, рівний з рівним».

Не дивно, що саме цей епізод поліція вимагала зняти у виставі, як крамольний і «мазепинський». Виразними були сцени, де СадовськийДорошенко приймав державні рішення. Вагомим був епізод, у якому гетьман вирішував запросити турецького хана на допомогу у боротьбі з ворогами. Рецензенти називали його «сценою-мрією Дорошенка»:

«Ох, дух займа, коли згадаю я

Про те, що жде Україну кохану!

Князівство ми закладемо своє

Обаполи Дніпра, зміцнимо межі,

Осадимо фортецями, і Січ

Узброємо напрочуд, щоб зуби

Всяк поламав, хто схтів би проглинуть

Україну. Владнаємо поспільство,

Наставим шкіл, колегій. Зацвіте

Україна хорошим, рясним цвітом

Під захистом Туреччини, а там,

Як підросте, то вб'ється пташка в пір'я,

То полетить у вирій вже сама

Без помочі. Невже се вже не мрія,

Не сон, не жарт?»

Майстерно й переконливо М. Садовський проводив кульмінаційну сцену вистави: Дорошенко в облозі військами Самуйловича і московського воєначальника Ромоданівського; і в цих безнадійних ситуаціях гетьман раптом наказує музикантам грати і йде в танок (Садовський був знаменитим танцівником): «Ну ж, шкварче грай! Танцює Дорошенко... Козак вмира, але не йде на ласку». Садовський був майстром високохудожнього танку в характері й обставинах, у яких перебував його персонаж. Оптимізм і високий патріотичний дух вселяв митець у звучання сцени, що мала характер безвихідного становища.

Саме ці сцени, разом із епізодами розмови гетьмана 3 дружиною Прісею (М. Малиш-Федорець) та матір'ю (Л. Ліницька) рецензент В. Королів називав «справжніми шедеврами і доведеними до апогея» [16].

Не можна не сказати і про те, що спектакль, у якому було багато епізодичних ролей, мусив вирізнятися своєю акторською психологічною ансамблевістю і вимагав великої уважності та напруження акторських сил кожного виконавця, бо в протилежному разі грандіозна постать Садовського-Дорошенка своєю могутністю могла $б$ приглушити другорядні персонажі. Міцною 
ансамблевою зіграністю і переконливим виконанням своїх навіть епізодичних, але важливих у ідейно-художньому звучанні постановки ролей, відзначилися I. Мар'яненко (Самуйлович), Л. Ліницька (мати Митродора), М. Петлішенко (Мазепа), Є. Рибчинський (московський посланець), О. Корольчук (Сірко), О. Полянська (полковниця Шульга), М. Малиш-Федорець (Пріся), Є. Хуторна (Галя).

Важлива роль у донесенні головної ідеї вистави відводилася постаті матері Дорошенка стариці Митродори. Вона з'являлась у найвідповідальніших моментах діянь та прийняття рішень гетьманом. У авторки Митродора - не лише мати Дорошенка, в останніх картинах вона приходила як провісниця і як символічно-узагальнена постать матері України. Л. Ліницькій було визначене надто складне завдання - відтворення не лише конкретно-психологічної особи матері гетьмана, а й донесення узагальнено-символічної постаті Жінки-України. I це артистці було цілком по силах. На цей час у неї виразно вже виявлялися риси модерністсько-витонченої гри. Вона «стала носі$€$ культу розуму, раціостриманості, виваженості». Микола Вороний порівнював іiї гру з раціональною грою Сари Бернар. «Вишукано-манерна, штучна гра цієї видатної артистки <...> сподобалася не всім. Але такий тип гри мав місце на українській сцені» $[5,19]$.

Перша значна сцена Ліницької-Митродори - не лише благословіння сина і його війська на боротьбу з ворогом, а чітка настанова, за що слід боротися:

«Сину,

Тобі господь високий дав талан,

Та пам'ятай, що мусиш так ти дбати,

Щоб не за славу, не за владу й честь,

Щоб ти ішов за сльози людські й горе

Й насущний хліб братам своїм добув $<\ldots .>$

Не спокушайсь на славу.

Не булаві, а людові служи,

I пам'ятай, що материнське серце

Не стішиш ти клейнодами...»

Навіть у віршованій формі діалогу артистка вміло знаходила психологічну правду, не позбавляючи його театрального піднесення, притаманного стилю класичної трагедії.

У традиційному жанрі мелодрами проходила друга сцена «Материнське прокляття», за те, що син віддає Україну у підданство турецькому султанові. Детально розроблена архітектонічно сцена мала чітку композиційну побудову від зав'язки до розв'язки. Спершу мати-монахиня вивідувала, чи правда, що син хоче віддати Україну під протекторат туркам. I, переконавшись, що це так, вступала у двобій:

«Мати. Сину,

На бусурман звіряєшся, та їм

Закон велить винищувать, губити

Всіх християн.

Дорошенко. А християнам що

Велить закон? Братів обороняти?

На те вони й наймають військо знов,

Щоб нас усіх тут вигубить дощенту».

У фіналі сцени неузгодженість поглядів та непорозуміння між персонажами призводить до материнського прокляття:

«Дорошенко. Нема того, хто б зупинив мене...

Мати. Т Так мій прокльон... Зречусь тебе навіки!

Не я тебе благаю, сльози й кров,

Що пролились вже тут по Україні,

Волають скрізь до тебе з-під землі!

Не розливай же ще їх, бо затопиш

Країну всю, лиши свої думки,

Од бусурман одкиньсь.

Дорошенко. Нi, нізащо!

Maти. Не одійдеш? Так хай же мій прокльон

Впаде на тебе каменем!»

Перед глядачем поставала постать люблячої матері, але і вольової та мужньої жінки-патріотки. Ситуація на Правобережжі загострювалась, здійснювалися передбачення матері. Турки поводилися як загарбники, а між українцями виникали постійні міжусобиці та біди, які підривали народне терпіння, авторитет Дорошенка падав. Розчарований політикою сусідів та завойовницькими діями Туреччини, Дорошенко вирішив зректися влади i скласти гетьманські клейноди.

Стежкою через макове червоне поле іде зовсім сліпа жінка, дві гарні коси з-під намітки спадають на плечі. Вона іде, спираючись на палицю, - це мати гетьмана. Образ матері артистка доносила у розвиткові - на початку вона проклинала сина за руїну на рідній землі, а в фіналі, збагнувши трагізм подій, - прощає і навіть виправдовує його вчинки. Третя сцена - поява матері, алегоричної постаті України (сліпа, знесилена, розшарпана, але вічно молода), тому голос Ліницької-стариці дзвінкий і молодечий з натиском на нижні регістри. Вона не може не визнати суцільної руїни на українській землі, але крізь сльози віщує Україні майбутне:

«Дорошенко. Мамо,

Скажи ж мені, невже ж мої думки, Й заміри всі, і всі мої змагання Загинули намарно, й тільки кров 


\section{Умила землю рідну всю?}

Мати. $\mathrm{Hi}$, сину,

Не згинуло життя твоє, і кров,

Проллята тут, не згинула даремно:

Я вирощу $\mathrm{ii}$, я переллю iï

В нових людей. I всі пекучі сльози,

Пролиті тут, квітками я зрощу,

І зацвіте Україна сльозами

Моїх синів померлих. Ти не вмреш...

Загояться мої криваві рани,

Пролине час, а й через млу віків

Світитиме зорею Дорошенко.

Та провідна зоря осяє шлях

Синам моїм ... Україні

Ти дав минуле, сину, і воно

Уродить нам прийдешнє».

Сцени Дорошенка 3 матір'ю наповнювали виставу високою символікою. Ліницька (Митродора) була переконливим втіленням збореної та згорьованої постаті української Жінки-Матері, захисниці усього живого на рідній землі; наснагою для борців за честь і славу, за народ, а також водночас алегоричним уособленням самої України, розтерзаної як своїми, так і чужоземними завойовниками, але незламної.

Роль стариці Митродори була не лише етапною у творчості Л. Ліницької в момент переходу iї до ролей літніх жінок, вона була вражаючою подією в історії всієї акторської діяльності на Україні. У театрі фактично вперше було виведено символічну узагальнену фігуру України як дійову особу. I це завдання блискуче вирішила Л. Ліницька, що мало вирішальне значення для успіху всієї вистави.

Згодом М. Садовський згадував: «Постава п’єси “Гетьман Дорошенко” викликала величезний інтерес не тільки в колах українського громадянства, але й взагалі. Це був < .. > “цвях" сезону, і коли вона йшла не більш як двічі на тиждень, то це тільки тому, що надзвичайно тяжка до виконання роль гетьмана Дорошенка, яку грав я» $[13$, 109]. Цей факт підтверджував один із учасників вистави П. Коваленко - «Миколі Карповичу важко було засвоювати колосальний текст, писаний білим віршем, який треба було місцями висловлювати в досить швидкому ритмі з великим емоційним навантаженням» $[7,136]$.

Про загальне враження від вистави залишив відгук критик В. Королів: «На аудиторію, що була переповнена вщерть, вистава зробила сильне враження. Безліч квітів, сильні овації виконавцям, привітання автору - все це надавало прем'єрі Старицької-Черняхівської урочистого характеру, зро- било першу виставу “Дорошенка” (яка - до речі, припала в день роковин його смерті) одмітним 3'явищем, що вийшло за рямці щоденного» [16].

Драматургія Л. Старицької-Черняхівської, як і п'єси В. Винниченка, С. Черкасенка, Г. Хоткевича, позначена пошуками нової театральності. «Драматургічна форма, яку вони витворювали й олітературнювали на українському грунті, мала прислужитися переборенню традицій народницького “живого”, або етнографічно-побутового, театру» $[8,21]$.

Нова п'єса Л. Старицької-Черняхівської «Крила» (1914), яка присвячена проблемам сучасного життя, написана авторкою у зовсім іншій поетико-стильовій манері, відмінній від історичних, з романтичним забарвленням, картин «Гетьмана Дорошенка». П'єса «Крила» відтворює життя інтелігенції і багато в чому перегукувалась із «Блакитною трояндою» Лесі Українки. На її звучанні можемо відчути вплив європейської драми таких авторів, як Ібсен, Гауптман, Чехов, Метерлінк та інших. У «Крилах» Л. Старицька-Черняхівська переконливо відтворила трагедію талановитої жінки-письменниці, хист якої гине, придушений атмосферою несприятливого сімейного життя. Свіжа ідея п'єси, як і нові засоби iii творення, а згодом і сценічне ії втілення, засвідчили, що український театр справді відходить від етнографічно-побутових барв, але залишається вірним провідній художній ознаці - правдивого відтворення характеру в усіх його зв'язках та опосередкуваннях. Авторка при написанні «Крил» використала прийом новітньої європейської драми, де основним засобом переважно було взято невідповідність справжнього внутрішнього стану персонажа його поведінці та вчинкам. Молода талановита письменниця Ліна, головна героїня «Крил», страждає і свої нестерпні муки від хатнього життя приховує до часу від сторонніх людей. Тривалий час залишається 3 ними наодинці і лише під фінал, шукаючи виходу із сімейної драми, відкриває обставини реальної дійсності. Правильно стверджує сучасний театрознавець Марина Гринишина: «Характер головної героїні п’єси Ліни Федорівни авторка сформувала згідно традицій європейської “нової” драми - показала, як та переживає негаразди родинного життя, поступово усвідомлює власне становище і ставлення до неї оточення» $[7,138]$.

Вже в експозиції цієї інтелектуальної драми відбувається суперечка письменника Василя Павловича і літератора Григорія Петровича про призначення сучасної жінки та ії право на само- 
реалізацію. А професор Іван Павлович, який протягом п'єси апелює зверненнями до античності, проводить аналогію характеру Ліни з двома типами античних героїнь - «перший приклад Аспазії, Сапфо, Діотіми, які “доглядали лише святий вогонь своєї творчості”, і другий приклад берегині родинного вогнища - Пенелопи». Під фінал драми професор порівнював «самовідданість Ліни 3 цілеспрямованістю Антігони, а “Антігони не вміли ніколи гаразд влаштовувати власне життя”». Подібні звернення дійових осіб до тем античності мали, за думкою авторки, скерувати дію п'єси на символічний характер. Та й, зрештою, «назва п'єси "Крила" символізує ідею творчого покликання митця і проектується на згадуваний в ситуації вагань героїні щодо права на самореалізацію міф про спалені сонцем крила Ікара» $[14,38]$. Античний міф про розплавлені воскові крила Ікара, бо той, хто має природні крила, може летіти назустріч сонцю.

Словами старого професора авторка утверджує вирок жіночій самореалізації: «Горе тій жінці, яка проміняла свій талант на втіхи родинного життя. Жінка, яка має талант, не повинна в'язати себе шлюбом, вона мусить лишатись вільною Аспазією, незалежною ні від кого, лише від свого таланту».

В основі сюжету п'єси - покладений авторкою старий мелодраматичний любовний трикутник. Молода перспективна письменниця Ліна живе в обстановці внутрішнього конфлікту між прагненням творчої реалізації і потребою жертвувати творчим покликанням заради збереження сімейного благополуччя і догляду за хворою дитиною. А чоловік, маститий адвокат Віктор, тим часом зраджує іiї з найближчою подругою Ліни, честолюбною оперною співачкою Іриною. За задумом драматурга цей трикутник мав би мати символічне звучання, та їй або не вдалося втілити таке звучання, або, зважаючи на стан сценічної практики, вона згладила цю барву спеціально, визначивши жанр п'єси «буденна драма». Перший рецензент п’єси I. Стешенко написав, що п’єса «задумана як новітня психологічна драма, але не написана на рівні кращих іiі зразків» $[19,94]$. Далі І. Стешенко зауважував, що «всю п’єсу збудовано на двох пружинах, далеко не буденного, а часом навіть виключного настрою» $[19,94]$. Теоретик навіть визначав можливості режисера у побудові головної лінії розвитку сюжету, при з'єднанні двох сюжетних розвитків: перша наскрізна лінія - це зрада талановитій молодій людині, друга - приборкання iï сімейними обставинами, i тут головним для ре- жисера було поєднати ці дві дієві пружини, щоб вибудувати одну наскрізну дію вистави.

Очевидець вистави В. Василько у щоденнику занотував (запис від 28 січня 1914 р.), що «нова драма Л. Старицької-Черняхівської належить до салонних п’єс» [4]. А критик Г. Александровський, рецензуючи виставу (прем'єра відбулася 23 січня 1914 р.), писав: «П'єса ця, яку написано в значній мірі по-чеховськи, в м'яких полутонах, вимагає таких же форм і з боку сценічної її постановки, і з боку виконання» $[1,99]$.

Постановку вистави здійснював сам М. Садовський, який мав гостре відчуття сценічності п'єси і користувався методикою акторської режисури. Можливо, режисер не завжди вирізнявся чіткими інтерпретаторськими засобами виразності п’єси, але мав великий смак до розробки переконливих сценічних характерів. Великої уваги при цьому він надавав художньому звучанню «музики слова» - багатство інтонаційного малюнка, мелодика, ритміка, наголоси, манера вимовляння. У цій п'єсі така робота над роллю і над собою становила першу необхідну умову. Щоправда, жоден 3 рецензентів не давав оцінки підготовчої роботи режисера над виставою. Лише Г. Александровський зауважив про вдалу розробку масових сцен у першій дії. Хоч тут слід пригадати старий театральний жарт про те, що в хорошій виставі режисерської праці не видно. А «Крила» була сильною постановкою, котра вражала визначним рівнем психологічної акторської ансамблевості. У газеті «Рада» писалося: «У “Крилах” і драматург, i артисти цим разом вийшли переможцями. <...> Окремі місця просто захоплювали глядачів. Прекрасна продумана гра артистів немало допомагала успіхові» [15].

Головні ролі у виставі виконували - Ліна Федорівна (Л. Ліницька), Віктор Олександрович (I. Мар'яненко), Ірина Павлівна (М. Малиш-Федорець), Письменник (М. Петлішенко), Літератор (С. Рибчинський), Професор (С. Паньківський), Патронеса (О. Полянська), Куховарка (П. Колесникова).

При величезному творчому багажеві Л. Ліницькій майже не доводилося грати ролей такого яскравого психологічного плану. Зрештою не лише їй. М. Вороний з цього приводу зауважував: «Майбутній актор нового репертуару з глибшим психологічним змістом щойно формувався, $\mathrm{i}$ потрібен був довгий час для його виховання» $[6$, 369]. Великою працею над собою, над процесом народження думки, а з нею донесення правди руху, слова і дії щоденно займалася артистка. І результат 
не забарився. У ролі Ліни Л. Ліницька намагалася не лише виявляти яскраві душевні переживання, а й те, що звалося «настроєм». Критик Г. Александровський писав, що у виставі: «Перше місце належить Ліницькій, що грала молоду письменницю Ліну. Артистка зуміла тими м'ягкими полутонами, в яких написана їі роль, без зайвих підкреслень, художньо змалювати привабливий образ, повний душевної чистоти та красоти, разом з тим і важку драму, яку вона переживала» $[1,100]$.

У сценічному втіленні Ліна Ліницької - інтелігентна молода особа, талановита письменниця. В успішній творчій роботі вона знаходить красу життя. Вона покохала популярного адвоката Biктора. Одружившись, віддала коханому чоловікові душу і серце. Прийшло материнство, яке приносить ій багато хвилювань та гризот, безсонні ночі, страждання біля хворої дитини, але все це творило ще повнішу гармонію щастя. Проте від творчості відривають всілякі господарчі дрібниці - перепечений пиріг, дрова, конфлікти служниць, часті гості і т. ін. Виходом із цього всього могла стати увага приват-доцента Віктора до цих сімейних дрібниць $\mathrm{i}$, передусім, - співчутливе ставлення до письменницького хисту своєї дружини, позбавлення іiї творчості від пирогів, сирих дров, гостей і всяких непорозумінь. Тоді дружина могла б творити і не почувалася б приниженою у своїй літературній праці та й 3 певного часу не була б самотньою. Але популярний адвокат - типовий панок, егоїст і хворіє на особливу тугу за красою життя. Він не може оцінити становище своєї дружини та задовольнятись атмосферою сімейного щастя і закохується у чарівну оперну співачку Ріну (М. Малиш-Федорець), найкращу подругу Ліни. Утворюється серйозна сімейна драма. Переконавшись у тім, що з чоловіком їй не по дорозі, Ліна глибоко переживає своє становище і в результаті зважується рішуче скінчити з неможливим життям та, віддавши перевагу творчості незалежної людини, кидає чоловіка 3 дитиною, йде від нього.

Рецензенти відзначали найкращі сцени у роботі Ліницької-Ліни - це, за творчою роботою, сцена з Ріною, прохання до Віктора не йти в театр на бенефісну виставу Ріни та фінальна сцена прощання з чоловіком.

В. Василько у щоденнику досить конкретно описав переважну більшість акторського виконання у виставі та найвище оцінював гру Ліницької - «найкраще враження на мене зробила гра Л. Ліницької. Мені здавалося, що я бачив чеховську героїню» [4]. Пізніше, у спогадах про твор- чість Ліницької, видатний митець писав: «Дивуєшся, яким чином вона (Л. Ліницька) знаходила в собі талант і силу одухотворяти ці надумані, а головне буденні сірі схеми і створювати на сцені живих людей. Лише вроджене благородство, інтелігентність і розум Ліницької рятували іiі на сцені від банальності і сірості. Актриса знаходила якісь свої психологічні нюанси і засоби, що підтримували увагу публіки» $[3,136]$.

Особливо майстерно Ліницька-Ліна проводила сцену прощання 3 чоловіком, у якій героїня поставала людиною сильної волі, розсудливою і рішучою: «Щастя не буде і шлюбу не було і не буде, поки чоловік не стане людиною, а замість одалісок прийдуть смілі і чисті жінки. Прощай, Віктор, ти дав мені багато горя, але за хороші хвилини спасибі - вони проросли в моїй душі». I мимоволі у героїні очі наповнювались сльозами, а глядачам надовго залишався у пам'яті фінальний плач Ліни під радісний закулісний спів і сміх Ірини. Гра Ліницької у ролі Ліни мала одностайні оцінки, яка базувалась «на півтонах» та «без зайвих підкреслень».

Тогочасні критики по-різному оцінювали гру партнерів Л. Ліницької. Так рецензент газети «Рада» зазначав, що «бездоганним був I. Мар'яненко, гра якого вище всяких компліментів» [15]. Інший критик Г. Александровський у грі I. Мар'яненка бачив суттєві недоробки - «актор не цілком зжився з психологією тої особи, яку виявляв з себе Віктор. У виконанні чувся іноді холодок, він губив часом простий і щирий тон і збивався на декламаційний пафос» [1, 101]. Про виконання ролі Ріни також не було однакових оцінок. У газеті «Рада» відзначалась сцена першої появи співачки, сцена 3 Ліною, де «артистка мала змогу виявити свій хист у тонкій передачі різнорідних почувань - від щирості й розпачу до образи і обурення» [15]. А згадуваний вже Г. Александровський писав про гру М. Малиш-Федорець зовсім інше. Вона у ролі Ріни здалася йому «занадто прямолінійною, без тонких нюансів, без того чогось, у якому міститься справжній артистизм, виявлялись здебільшого різкі, грубі тони, не потрібні в п'єсах такого типу. Це була іменно "гра", а не переживання, через що глядач слухав iї з холодним серцем» $[1,96]$.

У загальному плані всі дописувачі сходились на позитивній оцінці сценічного ансамблю вистави, майже всіх виконавців. Згадуваний рецензент «Ради» робив висновок, що «взагалі п’єса відіграна блискуче, прийнята $з$ початку публікою дещо стримано, але драма під кінець захопила і зробила враження» [15]. 
М. Садовський намагався засобами театру відобразити ще не бачені на українській сцені сторони життя. Тому його театр ішов у ногу з життям, $з$ передовою частиною діячів культури. Він підтримував шукання молодих драматургів, вони ж вливалися своїми творчими новаторськими пошуками в діяльність театру, несучи все нове й прогресивне, що 3'являлось у житті і драматургії. Певний час вистава «Крила» була окрасою репертуарної афіші театру. І цілком має рацію талановита дослідниця театральних процесів на Україні Г. Веселовська, стверджуючи, що в «сенсі розвитку новітніх шляхів сценічності постановка “Крил”, практично забутої істориками театру драми Л. Старицької-Черняхівської, важила не менше, а може й більше, ніж драматургія Лесі Українки» $[11,179]$.

Микола Садовський, як і всі шанувальники творчості його театру, зокрема Л. Старицька-Черняхівська, 3 оптимізмом сприйняли події Лютневої буржуазно-демократичної революції 1917 року. Вже 5 березня у Києві проходили масштабні маніфестації, у яких активну участь брала трупа театру М. Садовського, на мітингу співала «Заповіт» Т. Шевченка, революційні та народні пісні. Великим імпровізованим хором диригував сам Микола Карпович. Згодом розпочалося формування першого Національного уряду України - Центральної Ради України, до якого ні М. Садовський, ні Л. Старицька-Черняхівська не були сторонніми людьми. В умовах громадянської війни та іноземної інтервенції внутрішня ситуація у Києві набувала катастрофічного характеру як для усього населення, так і для діячів української культури. Майже одночасно 3 відходом з Києва уряду УНР Садовський заявив про виїзд з міста театру у січні 1919 року до м. Вінниці, а згодом до м. Кам'янця-Подільського. У Кам'янці-Подільському театр перебував з грудня 1919 по травень 1920 року. У складі театру працювало майже все його ядро - С. Черкасенко, В. Авраменко (пізніше видатний хореограф), актори - Г. Березовський, Н. Горленко, С. Іванова, Т. Івлєв, І. Ковалевський, О. Корольчук, М. Малиш-Федорець, М. Марченко, М. Миленко, В. Терентьєв, П. Чугуй та ін. У Вiнниці долучились до театру - Л. Болобан, Г. Ігнатович, Л. Липківський, В. Маслюченко, П. Нятко, М. Склярова, О. Швачко, а в Кам'янець-Подільську - Є. Коханенко, О. Левицький, М. Тінський та інші. До творчого складу театру входили чудові митці, яскраві особистості. У театрі працював художником А. Петрицький, а завідував музичною частиною М. Грінченко. Тому репертуар колек- тиву був змістовним і різноманітним - «Наталка Полтавка» I. Котляревського, «Запорожець за Дунаєм» С. Гулака-Артемовського, «Катерина» М. Аркаса, «Дві сім’ї» М. Кропивницького, «За двома зайцями» М. Старицького, «Сорочинський ярмарок» за М. Гоголем, «Лісова квітка» Л. Яновської, «Ясні зорі» Б. Грінченка. Серед прем’єрних постановок були - «Куди вітер віє» С. Васильченка, «Бояриня» Лесі Українки та «Останній сніп» Л. Старицької-Черняхівської (прем'єра січень 1920 p.).

П'єса «Останній сніп» написана у 1917 році, а відтворені у ній події належать до епохи Катерини II, зокрема, руйнування й знищення Запорозької Січі. Але відтворювала їх письменниця 3 передчуттям відродження незалежної України. Навесні 1917 року в Україні події розвивалися у руслі загальноросійської революції. Так, 1 травня 1917 року в Києві мирно розійшлися 3 різними гаслами три колони демонстрантів: більшовицька, армійська та прихильників Центральної Ради. Питання вірності та зради українському відродженню в умовах руйнівної анархії поставало дуже актуально. Авторка у драматичній формі «Останнього снопа» прекрасно відтворила, з одного боку, деморалізацію та ренегатство козацької старшини за часів Катерини II, а з іншого - вияскравила єдність поколінь: старого запорожця та його онучки Ганусі за збереження державності Запорозької Січі, жорстоко розтягнутої і знищеної хижими ворогами. Актуальність «Останнього снопа» визначалася суспільно-політичними паралелями між історичними подіями і сучасним станом боротьби за Україну. Навала російського війська Муравйова насувалась на Київ, знищуючи на своєму шляху все українське. Театрознавець Л. Барабан зазначав, що злободенність твору авторки у тому, що «він побачив світ у той момент, коли розбурханість суспільства, лихоліття військового часу, революційна дистрибуція, листопадові дні 1917 року принесли повний розгром українського культурно-національного життя» $[2,66]$.

Уперше твір «Останній сніп» був надрукований у Києві у видавництві товариства «Час» в 1917 році. Драматична дія п’єси розвивається в атмосфері складних психологічних запропонованих обставин життя людей у перші роки після знищення Запорозької Січі. Старий козацький полковник Андрій Нещадим намагається описати події знищення Січі, щоб залишити безцінний документ для нащадків. Та раптом йому приносять записки від давнього товариша, Переяславського полковника Ганжі, який був свідком падіння ко- 
зацької держави. У листі повідомляється, що Січ було знищено за допомоги зрадництва Кременчуцького полковника Семена Нещадима, який провів царське військо генерала Текелії таємними степовими дорогами. За це Семен отримав царські нагороди, чим зумів «своє життя прибрати в пишні шати». У відкритій суперечності батька 3 сином Семеном про негідні його зрадницькі вчинки на бік старого полковника стає його п'ятнадцятилітня онука Гануся, яка безмежно шанує дідуся і поділяє його тривоги, болі та думки. Дідусь та онука відстоюють лінію щирого й романтичного служіння ідеям козацької вольності, а Семен живе думками й вчинками раціонального пристосовництва до завойовників та поневолювачів, російських царедворців. Семен Нещадим, виправдовуючи свою зраду, заявляс: «Розважаю розумом, що треба скоритись, не битись марно, а вбиватися в колодочки помалу, Щоб задніх нам не пасти тут. Так, так, бо на чиєму возі, кажуть, їдеш - того й пісні співай».

Актуальний своїм змістом «Останній сніп» не залишив критиків та літературознавців байдужими. Відразу після виходу твору з друку авторитетний критик В. Королів (Старий В.) у часописі «Книгар» (1917 р., № 1) відзначав: «П’єса-мініатюра “Останній сніп” - невелика, але коштовна як з боку літературного, так і з боку сценічного < ..> Це канва того сумного малюнка 3 далекої минувщини, що покладена в основу історичного етюду Л. Старицької-Черняхівської, який з'явився на нашій сцені саме до речі в обставинах сучасності особливого інтересу. П'єса написана майстерно, 3 великим знанням сцени, білим віршем, добірною мовою, в якій додержано запашного історичного колориту» $[7,137]$.

Сучасні літературознавці у своїх дослідженнях відзначають наскрізну символіко-алегоричну образність «Останнього снопа», сильну «символізацію художньої образності», а посилаючись на твердження мистецтвознавця Я. Мамонтова, навіть виділяють три символічні образи п’єси: «Козака-лицаря Андрія Нещадима, який викриває колишню зраду свого сина і $є$ персоніфікованим втіленням символічного образу “останнього снопа"; ренегата Семена Нещадима, 3 діями якого пов'язана символіка “обжинків”, що стають знаком споживацького побуту; а також його дочки Ганусі, символічного втілення пісенної душі народу, українського народного духу» $[14,39]$. У своїй колективній праці авторки, підводячи підсумки, заключають: «Символічні образи драматичного етюду “Останній сніп” тяжіють до алегоричного прочитання і виявляють відверту ідеологічну авторську тенденційність» $[14,40]$. Але це, зрештою, накладає певні зобов'язання на сценічну образність. Можна погодитися 3 дослідниками, вони керуються літературною основою - текстом п'єси. Та слід зауважити, що символізм Л. Старицької певною мірою був поміркованим. Вона, звичайно, насамперед орієнтувалась на сценічне втілення свого твору. Хоч сучасний театрознавець Марина Гринишина тепер більш прискіпливо оцінює п’єсу Старицької. Не принижуючи їі виразного ідейного звучання, вона вказує про надмірний мелодраматизм, про трафаретну фабулу, шаблонний образ сина Семена та схематичний - старого Нещадима $[7,137]$. Певна доля правди в цьому $\epsilon$, хоч твір слід оцінювати не як чотири-п'ятиактну драму, а як одноактний драматичний етюд, п’єсу-мініатюру з колосальною конденсованістю діiі. Хоч з боку сценічної практики композиційна побудова подій є бездоганною, і постановка п“єси у прифронтовому театрі, що була однією 3 найкращих, мала історичне значення. «Виставу дивились вояки, січові стрільці, мирне населення, учні старших класів, студенти вузів, зосереджених у Кам'янці-Подільському, чиновники i державні мужі» $[9,113]$. На всіх виставах «Останнього снопа» можна було бачити письменників - П. Губенка (Остапа Вишню), I. Дніпровського, В. Сосюру, В. Свідзинського, Ю. Смолича, відвідували спектакль і керівники Директорії - В. Винниченко та С. Петлюра.

У виставі режисерську працю й виконання головної ролі Андрія Нещадима М. Садовський поклав на себе. Вистава, сповнена страдницькою долею України, стала алегоричним відтворенням сучасної дійсності, тому не залишала глядачів байдужими. У місцевій газеті «Наш шлях» постановку було названо «конгеніальною, і враження від того залишалось яскравим та живим уже назавжди» [12].

Шістдесятичотирирічний М. Садовський у роль Андрія вкладав увесь свій талант та уміння, тому у глядачів 3 першого моменту складалося враження як про величного й благородного мужа. Якщо роль Гетьмана Дорошенка була занадто об'ємною і складною, про яку митець заявляв сам, що при іiі виконанні він сильно втомлювався, то Андрія Нещадима актор грав буквально на одному подихові. Головним в образі було те, що митець виразно розподіляв характерні барви персонажа. Він надзвичайно лагідним і сердечним був зі своєю онукою Ганусею, коли вона злякалася постатей вуличного різдвяного вертепу, котрі 
відтворювали злих і фантастичних персонажів; а в фіналі «гарний, як орел», козак побив усіх ворогів та ще й пісню заспівав. Садовський-Нещадим, ласкаво пригортаючи Ганусю, сердечно говорив: «Унученько! Сама ти, наче пісня: Весела, дзвінка і сумна». На противагу грізно і по-батьківськи настирливо звучали слова Садовського-Андрія, сповнені внутрішнім драматизмом, синові Семенові про його прагнення догоджати російським правителям, алегорично втілювались у найважливішу селянську працю - завершення жнив:

«А! Скінчив...

Упорався. Іди ж, справляй обжинки,

Вже все пожав, усе домолотив,

Домолоти ж ще сніп оцей останній,

Та й розкошуй, мели і шеретуй,

Щоб не лишилось і зерна малого

Того життя. Души твоїх братів».

Багатолітній досвідчений воїн, патріот і охоронець рідної землі перед смертю з глибокою силою трагізму (як умів це робити видатний митець, неперевершений виконавець ролей Богдана Хмельницького і Тараса Бульби) проклинав зрадницькі діяння рідного сина:

«Продав усе, усе занапастив.

Так будь же ти, будь проклятий, Іуда!

Кляну тебе усім, що в світі $\epsilon$ !

Сльозами тими, що лились у Січі,

Землею рідною, нехай вона

Камінням труну твою покриє!

Кляну тебе всією кров'ю, що

Лилася тут колись за нашу волю.

Залийся нею, утопись!!»

Семен стояв неподалік і насміхався з батьківських прокльонів, а батько, не витримуючи глуму i наруги сина над козацькою честю та пам'яттю полеглих за волю козацької держави, втрачаючи свідомість, падав, мов беззахисний солом'яний сніп. Євген Маланюк, який перебував тоді у Кам'янець-Подільську, дивився декілька разів виставу і залишив свої враження про гру М. Садовського у ролі Нещадима, у якій досвідчений і неперевершений майстер перевтілення досягав у цьому образі апогею. А в передмові до видання драми «Останній сніп» у Нью-Йорку в 1958 році Є. Маланюк написав: «Навіть жупан, в якому виступав у ролі Андрія Нещадима М. Садовський, був підкреслено алегоричним солом'яного кольору. I коли М. Садовський падав, ранений на смерть сердечним ударом, то падав, як підтятий дуб, падав, справді, як важкий, злотавий сніп, не згинаючись, цілою своєю випростовано штивою старокозацькою статурою» $[18,67]$. В органічно- му художньому ансамблі разом з М. Садовським виступали Є. Іванова, О. Левицький, В. Стороженко, М. Асюкевич, Т. Демчук, П. Чугай та О. Шклярський.

Театр М. Садовського, проводячи свою прощальну декаду вистав у Кам'янець-Подільську, 13 травня показав спектакль «Останній сніп», це була остання вистава цього колективу, що розпочав свою діяльність Першого українського стаціонарного театру у Києві у 1907 році.

Різножанрові та різнотематичні п'єси «Гетьман Дорошенко», «Крила» та «Останній сніп» були окрасою репертуару цього славетного театру, що своєю творчістю пристрасно закликав глядачів до боротьби за соціальне та національне визволення, за цілісну й незалежну Україну. Сценічне втілення драматургії Л. Старицької-Черняхівської разом $з$ творами Лесі Українки, В. Винниченка, С. Черкасенка, Ю. Словацького, Л. Ріделя мало вирішальне значення для утворення театру європейського спрямування, а головне для виховання акторських сил модерністських стильових можливостей та вмінь, що давало надію сподіватися на оновлення вітчизняного театрального мистецтва.

У роки відродження незалежної України, іiі демократизації, замовчуване більшовицькою бюрократією та радянською владою ім'я талановитої і багатопланової діячки Людмили Старицької-Черняхівської повністю реабілітоване. Відкинено усі фальшиві та злісні звинувачення на їі адресу, а художня спадщина майстрині поволі повертається до духовного служіння та естетичного збагачення українського народу.

\section{Джерела та література}

1. Александровський Г. Український театр: «Крила» буденна драма на IV дії Л. Старицької-Черняхівської // Сяйво. 1914. - № 14. - C. 94-102.

2. Барабан Л. Людмила Старицька-Черняхівська. Тернистий шлях творчості / Л. І. Барабан. - Вінниця: «Велес».2003. $-89 \mathrm{c}$.

3. Василько В. Спогади про Ліницьку // Зб. Любов Павлівна Ліницька. - К. : Державне видавництво образотворчого мистецтва і музичної літератури, 1957. - 177 с.

4. Василько В. Щоденник 1914-1918 / Музей театрального, музичного та кіномистецтва України. - Ф. № 10369.

5. Веселовська Г. Театральні перехрестя Києва 19001910-х рр. / Ганна Веселовська. - К. : Гнозіс, 2007. - 326 с.

6. Вороний М. Театр і драма / Микола Вороний. - К. : Мистецтво, 1989. - $406 \mathrm{c}$.

7. Гринишина М. Театральна культура рубежу XIX-XX століть / Марина Гринишина. - К. : Фенікс,2013. - 342 с.

8. Історія української літератури ХХ століття / Книга перша; [за ред В. Г. Дончика]. - К. : Либідь, 1993. - 782 с.

9. Історія українського театру : т. 2 (1900-1945) ; [ред. кол. Г. А. Скрипник (голов. ред.) та ін.]. - К. : НАН України, ІМФЕ ім. М. Т. Рильського, 2009. - 866 с. 
10. Кисіль О. Український театр / Ол. Кисіль. - К. : Книгоспілка. $-1925 .-179$ с.

11. Нариси з історії театрального мистецтва України XX ст. ; [гол. наук. ред., упор. М. О. Гринишина, редкол. В. Сидоренко (голова) та ін]. - К. : ІПСМ АМУ, Інтертехнологія, 2006. $-1052 \mathrm{c}$.

12. Наш шлях / Кам'янець-Подільськ. $-1920 .-20$ квітня.

13. Садовський М. Мої театральні згадки / М. К. Садовський. - К.-Харків : Державне видавництво України, 1930. - 121 c.

14. Свербілова Т., Малютіна Н., Скорина Л. Від модерну до авангарду: жанрово-стильова парадигма української драматургії першої третини XX століття / Тетяна Свербілова, Наталя Малютіна, Людмила Скорина. - Черкаси, 2009. - 598 с

15. Ст. Театр і музика. Бенефіс С. Паньківського. «Крила» // Рада. - 1914. - 25 січня.

16. Старий В. [Королів В.]. Український театр // Рада. 1911. - 11 листопада.

17. Старицька-Черняхівська Л. Вибрані твори / Людмила Старицька-Черняхівська. - К. : Наукова думка, 2000. $598 \mathrm{c}$.

18. Старицька-Черняхівська Л. Останній сніп. - Нью-Йорк, 1958. $-78 \mathrm{c}$.

19. Стешенко I. «Крила». Буденна драма на IV дії Л. Старицької-Черняхівської / Іван Стешенко // Сяйво. - 1914. № 14. - С. 94-96.

20. Чаговець В. «Гетьман Дорошенко» / В. Чаговец // Киевская мысль. - 1911. - 12 ноября.

\section{References}

1. Aleksandrovskyi, H. (1914). Ukrainskyi teatr: «Kryla» budenna drama na IV dii L. Starytskoi-Cherniakhivskoi // Siaivo. - № 14. - S. 94-102 [in Ukrainian].

2. Baraban, L. (2003). Liudmyla Starytska-Cherniakhivska. Ternystyi shliakh tvorchosti (2003). - Vinnytsia: «Veles», 89 [in Ukrainian].

3. Vasylko, V. (1957). Spohady pro Linytsku // Zb. Liubov Pavlivna Linytska. - K. : Derzhavne vydavnytstvo obrazotvorchoho mystetstva i muzychnoi literatury, 177 [in Ukrainian].
4. Vasylko, V. Shchodennyk 1914-1918 / Muzei teatralnoho, muzychnoho ta kinomystetstva Ukrainy. - F. № 10369.

5. Veselovska, H. (2007). Teatralni perekhrestia Kyieva 19001910-kh rr. - K. : Hnozis, 326 [in Ukrainian].

6. Voronyi, M. (1989). Teatr i drama. - K. : Mystetstvo, 406 [in Ukrainian].

7. Hrynyshyna, M. (2013). Teatralna kultura rubezhu - XIXXX stolit. - K. : Feniks, 342 [in Ukrainian].

8. Istoriia ukrainskoi literatury $\mathrm{XX}$ stolittia / Knyha persha ; [za red V. H. Donchyka] (1993). - K. : Lybid, 782 [in Ukrainian].

9. Istoriia ukrainskoho teatru : t. 2 (1900-1945); [red. kol. H. A. Skrypnyk (holov. red.) ta in.] (2009). - K. : NAN Ukrainy, IMFE im. M. T. Rylskoho, 866 [in Ukrainian].

10. Kysil, O. (1925). Ukrainskyi teatr. - K. : Knyhospilka, 179 [in Ukrainian].

11. Narysy z istorii teatralnoho mystetstva Ukrainy XX st. ; [hol. nauk. red., upor. M. O. Hrynyshyna, redkol. V. Sydorenko (holova) ta in] (2006). - K. : IPSM AMU, Intertekhnolohiia, 1052 [in Ukrainian].

12. Nash shliakh (1920) / Kamianets-Podilsk. - 20 kvitnia [in Ukrainian].

13. Sadovskyi, M. (1930). Moi teatralni zghadky. - K.-Kharkiv : Derzhavne vydavnytstvo Ukrainy, 121 [in Ukrainian].

14. Sverbilova, T., Maliutina, N., Skoryna L. (2009). Vid modernu do avanhardu: zhanrovo-stylova paradyhma ukrainskoi dramaturhii pershoi tretyny XX stolittia. - Cherkasy, 598 [in Ukrainian].

15. St. Teatr i muzyka. Benefis S. Pankivskoho. «Kryla» (1914)// Rada. - 25 sichnia [in Ukrainian].

16. Staryi, V. [Koroliv, V.] (1911). Ukrainskyi teatr // Rada. - 11 lystopada [in Ukrainian].

17. Starytska-Cherniakhivska, L. (2000). Vybrani tvory. - K. : Naukova dumka, 598 [in Ukrainian].

18. Starytska-Cherniakhivska, L. (1958). Ostannii snip. - NiuYork, 78 [in Ukrainian].

19. Steshenko, I. (1914). «Kryla». Budenna drama na IV dii L. Starytskoi-Cherniakhivskoi // Siaivo. -№ 14. - S. 94-96 [in Ukrainian].

20. Chahovets, V. (1911). «Hetman Doroshenko»// Kyevskaia musl. -12 noiabria [in Ukrainian]. 